\title{
CST5 wt Allele
}

National Cancer Institute

\section{Source}

National Cancer Institute. CST5 wt Allele. NCI Thesaurus. Code C159795.

Human CST 5 wild-type allele is located in the vicinity of 20p11.21 and is approximately 3 $\mathrm{kb}$ in length. This allele, which encodes cystatin-D protein, plays a role in cathepsin inhibition. 